\title{
Evaluasi Program Pembelajaran dalam Jaringan di Sekolah Menengah Kejuruan
}

\author{
Randi Winanda ${ }^{1 *}$, Nizwardi Jalinus ${ }^{2}$ (iD \\ 1,2 Program Studi Magister Teknologi dan Kejuruan, Fakultas Teknik, Universitas Negeri Padang, Padang, Indonesia \\ *Corresponding author: nandasutan3@gmail.com
}

\begin{abstract}
Abstrak
Terdapat beberapa masalah dalam implementasi pembelajaran dalam jaringan (Daring). Salah satunya yaitu belum pernah dilakukannya evaluasi program pembelajaran daring. Penelitian ini bertujuan untuk mengevaluasi komponen konteks, masukan, proses, dan hasil pada pembelajaran dalam jaringan (daring) di sekolah menengah kejuruan. Jenis penelitian adalah penelitian evaluasi dengan model evaluasi CIPP (Context, Input, Process, Product). Metode yang digunakan adalah metode kuantitatif. Data kuantitatif dikumpulkan melalui angket dan dianalisis dengan analisis deskriptif menggunakan tingkat pencapaian responden. Hasil penelitian menunjukkan bahwa komponen konteks, masukan, proses, dan hasil pada program pembelajaran daring di sekolah menengah kejuruan berada pada kategori cukup. Komponen proses dan komponen hasil perlu diperbaiki supaya pembelajaran daring dapat dilaksanakan secara optimal. Berdasarkan temuan penelitian dapat direkomendasikan pembelajaran daring dapat dilanjutkan dengan melakukan perbaikan pada setiap komponennya. Pendidik dan peserta didik yang terlibat di dalam implementasi pembelajaran daring perlu meningkatkan wawasan dan ilmu pengetahuan mengenai perkembangan teknologi. Implikasi dari penelitian ini adalah perlunya pihak sekolah melengkapi dan memperbaharui sarana dan prasarana sekolah, memberikan motivasi kepada pendidik dan peserta didik untuk lebih aktif di dalam implementasi pembelajaran daring.
\end{abstract}

Kata kunci: Evaluasi, Model CIPP, Pembelajaran Daring

\section{Abstract}

There are several problems in the implementation of online learning. One of them is that there has never been an evaluation of online learning programs. This study aims to evaluate the components of context, input, process, and outcomes in online learning in vocational high schools. The type of research is evaluation research with CIPP evaluation model (Context, Input, Process, Product). The method used is a quantitative method. Quantitative data were collected through questionnaires and analyzed by descriptive analysis using the level of achievement of the respondents. The results showed that the components of context, input, process, and outcomes in online learning programs in vocational high schools were in the sufficient category. Process components and outcome components need to be improved so that online learning can be carried out optimally. Based on the research findings, it can be recommended that online learning can be continued by making improvements to each of its components. Educators and students involved in the implementation of online learning need to increase their insight and knowledge about technological developments. The implication of this research is the need for schools to equip and update school facilities and infrastructure, to motivate educators and students to be more active in the implementation of online learning.

Keywords: Evaluation, CIPP Model, Online Learning

\section{INTRODUCTION}

Surat edaran nomor 36962/MPK.A/HK 2020 tentang pembelajaran secara daring dan bekerja di rumah dalam pencegahan COVID 19 bagi pendidik dan peserta didik di seluruh jenjang se-Indonesia (Ayuni et al., 2020; Ding et al., 2020). Bukan hanya di Indonesia, melainkan di seluruh dunia melaksanakan pembelajaran daring dan bekerja di rumah. Hal ini didukung dengan data UNESCO yang menyatakan lebih dari 850 juta siswa di seluruh dunia tidak belajar di sekolah (Cahyati \& Kusumah, 2020; Jariyah \& Tyastirin, 2020). Sistem pembelajaran daring (dalam jaringan) merupakan sistem pembelajaran tanpa tatap muka secara langsung antara guru dan siswa tetapi dilakukan melalui online yang menggunakan jaringan internet (Kusuma \& Sutapa, 2020; Rigianti, 2020). Guru harus memastikan kegiatan belajar mengajar tetap berjalan, meskipun siswa berada di rumah. Solusinya, guru dituntut dapat mendesain media pembelajaran sebagai inovasi dengan memanfaatkan media daring

$\begin{array}{ll}\text { History: } & \\ \text { Received } & \text { : September 03, } 2021 \\ \text { Revised } & \text { : September 05, } 2021 \\ \text { Accepted } & \text { : October 12, 2021 } \\ \text { Published } & \text { : October 25, } 2021\end{array}$


(online) (Naserly, 2020; Nurhayati et al., 2020). Hal ini sesuai dengan Surat Edaran Menteri Pendidikan dan Kebudayaan Republik Indonesia Nomor 4 Tahun 2020 tentang Pelaksanaan Kebijakan Pendidikan dalam Masa Darurat Penyebaran Corona Virus Disease (COVID-19) (Arizona et al., 2020; Damayanthi, 2020).

Melihat kondisi pendidikan di Indonesia, saat ini pemerintah mewajibkan seluruh siswa, bahkan mahasiswa untuk belajar jarak jauh (daring) yang dilakukan dalam kurun waktu tertentu (Nengrum et al., 2021; Sadikin \& Hamidah, 2020). Hal ini dilakukan sebagai salah satu bentuk upaya Negara Indonesia dalam mencegah penularan Covid-19 dan tetap meningkatkan kualitas pendidikan di tengah pandemi Covid-19. Perlunya penguasaann teknologi mau tidak mau harus dilakukan baik siswa maupun bagi pendidik. Hal tersebut menjadi tantangan tersendiri bagi guru untuk memaksimalkan proses pembelajaran secara daring, dan tantangan bagi siswa untuk mengerti materi dan tugas-tugas yang diberikan saat pembelajaran daring (Surahman et al., 2020; Wahyono et al., 2020). Sistem pembelajaran dilaksanakan melalui perangkat personal computer (PC), laptop serta smartphone yang terhubung dengan koneksi jaringan internet (Yuzulia, 2021). Guru dapat melakukan pembelajaran bersama diwaktu yang sama menggunakan grup di media sosial seperti WhatsApp (WA), telegram, instagram, aplikasi zoom, aplikasi google classroom ataupun media lainnya sebagai media pembelajaran (Basilaia \& Kvavadze, 2020; Naserly, 2020). Dengan demikian guru dapat memastikan siswa mengikuti pembelajaran dalam waktu yang bersamaan, meskipun di tempat yang berbeda. Perlu disadari bahwa ketidaksiapan guru dan siswa terhadap pembelajaran daring juga menjadi masalah. Perpindahan sistem belajar konvensional ke sistem daring amat mendadak, tanpa persiapan yang matang (Ayuni et al., 2021). Tetapi semua ini harus tetap dilaksanakan agar proses pembelajaran dapat berjalan lancar dan siswa aktif mengikuti walaupun dalam kondisi pandemi Covid-19.

Kabupaten Tanah Datar yang dikenal sebagai "Luhak Nan Tuo" merupakan salah satu wilayah yang terletak di tengah-tengah Propinsi Sumatera Barat dengan ibu kota Batusangkar. Kabupaten Tanah Datar terletak di antara dua gunung, yaitu Gunung Merapi dan Gunung Singgalang. Kondisi topografi ini didominasi oleh daerah perbukitan. SMK N 1 Tanjung Baru merupakan salah satu dari lima Sekolah Menengah Kejuruan Negri yang berada di kabupaten tanah datar. Empat dari lima sekolah kejuruan ini berada di kecamatan yang jauh dari jangkauan jaringan internet, hal ini menyebabkan masyarakat kabupaten Tanah Datar gagap teknologi. Hasil Survei Sosial Ekonomi Daerah (SUSEDA) dinas Komunikasi dan Informatika kabupaten Tanah Datar pada tahun 2020 menunjukan 66,81\% masyaraat tanah datar belum pernah mengakses internet. Berdasarkan data dinas komunikasi dan informatika kabupaten tanah datar dapat dilihat tidak ada kecamatan pengguna internetnya lebih dari 50\%, hal ini sesuai dengan hasil wawancara dengan Bapak Asvetinius Kepala Sekolah Menengah Kejuruan Negeri 1 Lintau Buo, Kabupaten Tanah Datar mengungkapkan, lokasi SMK N 1 Lintau Buo terpencil dan jauh dari ibukota kabupaten, lokasi sekolah berjarak sekitar 10 Kilometer dari ibukota kabupaten Batusangkar dengan akses jalan melewati perbukitan. Jaringan internet yang minim menjadi kendala untuk melaksanakan kegiatan belajar mengajar secara daring. Belum ada jaringan internet yang memadai. Bapak Asvetinius menambahkan guru-guru disekolahnya masih mengalami kesulitan dalam pelaksanaan kegiatan belajar mengajar) secara daring. saat ini ia beserta 7 orang tenaga pendidik lainya memanfaatkan jaringan internet dari sekolah lain yang jaraknya kurang lebih 1 Kilometer dari sekolah tempat mereka mengajar.

Peneliti menemukan permasalahan lain, keterbatasan pembelajaran daring disekolah SMK N 2 Batusangkar adalah kuota internet bagi tenaga pendidik dan siswa. Meskipun para tenaga pendidik sudah mendapatkan kuota subsidi dari Kemendikbud sebesar 15GB, tak dapat dipungkiri kuota tersebut belum bisa memenuhi untuk pembelajaran selama satu bulan. Kepala sekolah SMK N 2 Batusangkar mengungkapkan belum semua tenaga pendidik 
mendapatkan kuota subsidi tersebut, tak jarang mereka mengeluarkan dari kantong pribadi untuk memenuhi kuota internetnya. Berdasarkan hasil wawancara singkat dengan Kepala Sekolah SMKN 1 Tanjung Baru di Kabupaten Tanah datar terkait pelaksanaan pembelajaran dalam jaringan selama pandemi menyebutkan bahwa kendala terbesar dari pembelajaran daring di sekolah yang beliau pimpin adalah fasiltas yang dimiliki oleh siswa karena tidak semua siswa memiliki smartphone, laptop, dan notebook. Sekolah SMK N 1 Tanjung baru terletak pada kecamatan Tanjung baru yang pengguna internetnya masih $26,86 \%$, hal ini menjadi permasalahan lain yang dihadapi oleh sekolah dalam pelaksanaan KBM.

Tantangan lain yang dihadapi saat pembelajaran daring menurut Bapak Yusri Haryoga salah seorang Guru Produktif Di SMKN 1 Tanjung Baru adalah kemampuan guru dan siswa dalam memanfaatkan aplikasi-aplikasi yang digunakan dalam pembelajaran dalam jaringan yang belum maksimal sehingga proses pembelajaran hanya berlangsung sebatas pengambilan absen serta pemberian materi, Selain itu pembelajaran praktek tidak dapat di implementasikan karena siswa tidak memiliki fasilitas praktek dirumah padahal sekolah menengah kejuruan dituntut untuk melatih keterampilan sesuai dengan kopetensi. Permasalahan yang selanjutnya bukan hanya terdapat pada sistem media pembelajaran akan tetapi ketersediaan kuota internet yang membutuhkan biaya cukup tinggi harganya bagi siswa hal ini disampaikan oleh Bainar salah seorang orang tua siswa, guna memfasilitasi kebutuhan pembelajaran daring dia harus mengeluarkan uang tambahan dari pengeluaran normal untuk menunjang proses pembelajaran anaknya. banyak diantara orangtua siswa SMK N 1 Tanjung Baru yang tidak siap untuk menambah anggaran dalam menyediakan jaringan internet. Hal ini pun menjadi permasalahan yang sangat penting bagi siswa, jam berapa mereka harus belajar dan bagaimana data (kuota) yang mereka miliki, sedangkan orangtua mereka yang berpenghasilan rendah atau dari kalangan menengah kebawah (kurang mampu). Hingga akhirnya hal seperti ini dibebankan kepada orangtua siswa yang ingin anaknya tetap mengikuti pembelajaran daring.

Pembelajaran daring tidak bisa lepas dari jaringan internet. Koneksi jaringan internet menjadi salah satu kendala yang dihadapi siswa yang tempat tinggalnya sulit untuk mengakses internet, apalagi siswa tersebut tempat tinggalnya di daerah pedesaan, terpencil dan tertinggal. Kalaupun ada yang menggunakan jaringan seluler terkadang jaringan yang tidak stabil, karena letak geografis Tanjung Baru dan sekitarnya yang masih jauh dari jangkauan sinyal seluler. Hal ini juga menjadi permasalahan yang banyak terjadi pada siswa SMK N 1 Tanjung Baru yang mengikuti pembelajaran daring sehingga kurang optimal pelaksanaannya. Mengacu pada permasalahan di atas, maka peneliti memandang perlu dilakukan evaluasi terhadap implementasi pembelajaran dalam jaringan (Daring) untuk mengungkap seluruh permasalahan yang ada di dalam implementasi. Evaluasi ini diharapkan bisa menghasilkan hal-hal yang perlu dibenahi dalam implemnetasi pembelajaran dalam jaringan (Daring). Apabila suatu program tidak dievaluasi maka tidak dapat diketahui bagaimana dan seberapa baik kebijakan yang sudah dikeluarkan dapat terlaksana. Sedangkan bagi peserta didik evaluasi pembelajaran daring ini berfungsi sebagai umpan balik dalam meningkatkan kemampuan kompetensi dan hasil belajar.

Selain itu, evaluasi terhadap implementasi pembelajaran daring ini penting dilaksanakan karena belum pernah dilakukan evaluasi sebelumnya. Evaluasi program merupakan suatu proses sistematis untuk mengumpulkan, menganalisis, dan memakai informasi untuk menjawab pertanyaan dasar mengenai program. Evaluasi program ini bertujuan untuk melihat sejauh mana pembelajaran dalam jaringan (Daring) telah dilaksanakan dan hambatan apa saja yang ditemui selama proses implementasi. Evaluasi program memiliki banyak model dan salah satu model dari evaluasi program adalah model CIPP (Context, Input, Process, dan Product). Model CIPP merupakan model dengan tujuan utamanya adalah untuk memperbaiki. Model CIPP ini meliputi empat komponen yaitu 
komponen konteks (tujuan, kebutuhan, dan lingkungan dari implementasi pembelajaran dalam jaringan (daring)), komponen masukan (SDM, sarana prasarana, dan dana), komponen proses (implementasi pembelajaran dalam jaringan (daring)), dan komponen hasil. Evaluasi pembelajaran dalam jaringan (daring) ini diharapkan dapat menjadi rekomendasi bagi para pendidik khususnya pendidik pada Sekolah Menengah Kejuruan Negeri 1 Tanjung Baru dalam pengambilan keputusan yang berhubungan dengan proses pembelajaran dalam jaringan (daring) guna lebih baik di masa yang akan datang.

\section{MATERIALS AND METHODS}

Penelitian ini merupakan penelitian evaluasi dengan model Context, Input, Process, Product (CIPP) (Bhakti, 2017; Sugiyono, 2014). Dalam hal ini peneliti mengevaluasi implementasi pembelajaran dalam jaringan (daring) di SMK N 1 Tanjung baru ditinjau dari (a) Konteks, (b) masukan, (c) Proses, dan (d) Produk. Penelitian ini menggunakan pendekatan kuantitatif. Instrumen yang digunakan dalam pendekatan kuantitatif adalah kuesioner (angket). Angket diberikan kepada peserta didik. Setelah penyebaran instrumen kemudian dilakukan analisis terhadap data yang telah diperoleh untuk mengetahui tingkat pencapaian responden pada masing-masing indikator. Hasil analisis data kuantitatif ini dilakukan untuk pengambilan kesimpulan dan rekomendasi dari masing-masing indikator. Sampel dalam penelitian ini adalah peserta didik kelas XI TKJ dan kelas XI TKR tahun ajaran 2021/2022 pada SMK N 1 Tanjung Baru sebanyak 4 (empat) kelas terdiri dari 57 orang peserta didik. Teknik pengumpulan data dengan pendekatan kuantitatif yang digunakan dalam penelitian ini yaitu kuesioner (angket). Dalam penelitian ini menggunakan angket tertutup, dimana komunikasi dilakukan dengan cara tidak langsung. Responden diminta untuk memilih satu jawaban yang sesuai dengan karakteristik dirinya dengan cara memberikan tanda silang $(\mathrm{x})$ atau tanda checklist $(\sqrt{ })$. Kuesioner disusun berdasarkan penelitian evaluasi dengan model Context, Input, Process, Product (CIPP) menggunakan skala likert yaitu dengan lima alternatif jawaban. Jawaban tersebut mempunyai skor minimal dan maksimal.

\section{RESULTS AND DISCUSSION}

Result

Hasil penelitian evaluasi tentang implementasi pembelajaran daring di SMK N 1 Tanjung Baru dengan model Context, Input, Process, Product (CIPP).

\section{Evaluasi Konteks}

Evaluasi konteks pada penelitian ini dibagi dalam tiga indikator yaitu: 1) Tujuan, 2) Lingkungan yang mendukung, dan 3) Kebutuhan terhadap implementasi pembelajaran dalam jaringan dalam bentuk distribusi frekuensi dapat dilihat pada Tabel 1. Berdasarkan Tabel 1, komponen konteks dapat dikatakan baik dalam hal implementasi pembelajaran daring di SMK Negeri 1 Tanjuang Baru. Namun perlu ditingkatkan lagi untuk tingkat pencapaian yang lebih baik ke depannya.

Tabel 1. Hasil Evaluasi Konteks

\begin{tabular}{clcccc}
\hline No & \multicolumn{1}{c}{$\begin{array}{c}\text { Indikator } \\
\text { Level 1 }\end{array}$} & $\begin{array}{c}\text { Skor } \\
\text { rerata }\end{array}$ & $\begin{array}{c}\text { Skor } \\
\text { maks }\end{array}$ & $\begin{array}{c}\text { TPR } \\
\text { \% }\end{array}$ & Kategori \\
\hline 1 & Tujuan & 4,11 & 5 & 82,11 & Baik \\
2 & Lingkungan yang mendukung & 4,00 & 5 & 80,06 & Baik \\
3 & Kebutuhan terhadap implementasi & 4,07 & 5 & 81,36 & Baik \\
\hline
\end{tabular}




\section{Evaluasi Masukan}

Evaluasi Masukan pada penelitian ini dibagi dalam tiga indikator yaitu: 1) Sumber Daya Manusia, 2) sarana dan prasarana, dan 3) biaya. Hasil penelitian dari Evaluasi Masukan dalam bentuk distribusi frekuensi dapat dilihat pada Tabel 2.

Tabel 2. Hasil Evaluasi Masukan

\begin{tabular}{clcccc}
\hline No & \multicolumn{1}{c}{$\begin{array}{c}\text { Indikator } \\
\text { Pertanyaan }\end{array}$} & $\begin{array}{c}\text { Skor } \\
\text { rerata }\end{array}$ & $\begin{array}{c}\text { Skor } \\
\text { maks }\end{array}$ & $\begin{array}{c}\text { TPR } \\
\text { \% }\end{array}$ & Kategori \\
\hline 1 & Pendidik & 4,10 & 5 & 81.14 & Baik \\
2 & Peserta didik & 4,64 & 5 & 82,47 & Baik \\
3 & Sarana dan Prasarana & 4,93 & 5 & 78,69 & Baik \\
\hline
\end{tabular}

\section{Evaluasi Proses}

Evaluasi Proses pada penelitian ini dibagi dalam enam indikator yaitu: 1) Pelaksanaan, 2) Pelatihan, 3) Pemanfaatan Pembelajaran, 4) Pemanfaatan Prasarana, 5) Hambatan dan 6) solusi dari hambatan implementasi. Hasil penelitian dari evaluasi proses dalam bentuk distribusi frekuensi dapat dilihat pada Tabel 3.

Tabel 3. Evaluasi Proses

\begin{tabular}{clcccc}
\hline No & \multicolumn{1}{c}{ Indikator Pertanyaan } & $\begin{array}{c}\text { Skor } \\
\text { rerata }\end{array}$ & $\begin{array}{c}\text { Skor } \\
\text { maks }\end{array}$ & $\begin{array}{c}\text { TPR } \\
\text { \% }\end{array}$ & Kategori \\
\hline 1 & $\begin{array}{l}\text { Pelaksanaan pembelajaran dalam } \\
\text { jaringan (Daring). }\end{array}$ & 3,86 & 5 & 77,14 & Cukup \\
2 & $\begin{array}{l}\text { Pelatihan sumber daya manusia. } \\
\begin{array}{l}\text { Pemanfaatan pembelajaran daring dalam } \\
\text { kegiatan penilaian hasil belajar }\end{array}\end{array}$ & 3,57 & 5 & 71,33 & Cukup \\
4 & $\begin{array}{l}\text { Pemanfaatan sarana prasarana dalam } \\
\text { pembelajaran dalam jaringan (Daring). }\end{array}$ & 4,03 & 5 & 80,63 & Baik \\
5 & $\begin{array}{l}\text { Hambatan dalam implementasi } \\
\text { pembelajaran dalam jaringan (Daring). }\end{array}$ & 3,88 & 5 & 77,52 & Cukup \\
6 & \begin{tabular}{l} 
Solusi dari hambatan \\
\hline
\end{tabular} & 4,34 & 5 & 86,71 & Baik \\
\hline
\end{tabular}

\section{Evaluasi Hasil}

Evaluasi hasil pada penelitian ini dibagi dalam dua indikator yaitu: 1) Peningkatan pengetahuan dan 2) Perbaikan keterampilan. Hasil penelitian dari komponen level 4 hasil dalam bentuk distribusi frekuensi dapat dilihat pada Tabel 4.

Tabel 4. Komponen Level 4 Hasil

\begin{tabular}{crcccc}
\hline No & $\begin{array}{r}\text { Indikator } \\
\text { Pertanyaan }\end{array}$ & Skor rerata & Skor maks & $\begin{array}{c}\text { TPR } \\
\boldsymbol{\%}\end{array}$ & Kategori \\
\hline 1 & Hasil implementasi & 4,01 & 5 & 80,29 & Baik \\
\hline
\end{tabular}

\section{Discussion}

Berdasarkan hasil penelitian yang telah dijabarkan, maka ditinjau dari model penelitian evaluasi dengan model Context, Input, Process, Product (CIPP) pembelajaran 
dalam jaringan (daring) di SMK N 1 Tanjung Baru akan dibahas sesuai dengan masing masing tahapan tersebut.

\section{Komponen Kontex (Context)}

Komponen konteks dalam implementasi pembelajaran dalam jaringan (daring) di SMK Negeri 1 Tanjuang Baru terbagi dalam tiga indikator/sub indikator yang ditinjau dari tujuan implementasi pembelajaran dalam jaringan (daring), lingkungan implementasi pembelajaran dalam jaringan (daring) dan kebutuhan terhadap implementasi pembelajaran dalam jaringan (daring). Berdasarkan angket yang disebarkan kepada 70 orang peserta didik dengan 15 butir pernyataan, diperoleh hasil untuk indikator tujuan sebesar 4,11 dengan tingkat pencapaian sebesar $82,11 \%$ dan termasuk ke dalam kategori baik. Artinya implementasi pembelajaran dalam jaringan (daring) membantu peserta didik belajar secara mandiri, memudahkan dalam mencari sumber belajar, meningkatkan wawasan dan ilmu pengetahuan, memungkinkan tersedianya komunikasi efektif, dan meningkatkan keinginan peserta didik untuk belajar.

Hasil untuk indikator lingkungan diperoleh rata-rata sebesar 4,7 dengan tingkat pencapaian sebesar 81,36\% dan termasuk ke dalam kategori baik. Artinya lingkungan implementasi pembelajaran dalam jaringan (daring) sudah mendukung untuk implementasi pembelajaran dalam jaringan (daring). Sekolah memberikan kenyamanan bagi pendidik dan peserta didik dalam mengimplementasikan pembelajaran dalam jaringan (daring). Disamping itu sekolah juga memberikan semangat dalam pembelajaran dalam jaringan (daring). Hasil untuk indikator kebutuh an diperoleh rata-rata sebesar 4,07 dengan tingkat pencapaian sebesar $81,36 \%$ dan termasuk ke dalam kategori baik. Artinya kebutuhan terhadap implementasi pembelajaran dalam jaringan (daring) sudah baik. Hal ini dilihat dari kondisi sarana dan prasarana yang tidak memenuhi kebuhutan, seperti perangkat komputer yang rusak, jaringan yang kurang bagus, pemadaman listrik, dan sebagainya.

Skor perolehan rata-rata dari ketiga indikator/sub indikator terkait komponen konteks implementasi pembelajaran dalam jaringan (daring) diperoleh sebesar 4,06 dengan tingkat pencapaian $81,18 \%$ dan termasuk ke dalam kategori baik. Dengan demikian dapat disimpulkan bahwa komponen konteks perlu ditingkatkan dan dioptimalkan untuk indikator tujuan dan lingkungan, dan perlu diperbaiki untuk indikator kebutuhan terhadap implementasi pembelajaran dalam jaringan (daring). Berdasarkan penjelasan di atas dapat disimpulkan bahwa implementasi pembelajaran dalam jaringan (daring) pada dasarnya bermanfaat bagi peserta didik dan pendidik. Tujuan implementasi pembelajaran dalam jaringan (daring) dapat dicapai apabila kebutuhan pendidik dan peserta didik akan implementasi terpenuhi dan lingkungan sekolah juga mendukung implemnetasi pembelajaran dalam jaringan (daring). Komponen konteks yang telah dievaluasi dan memperoleh hasil cukup perlu dilakukan perbaikan dan pengoptimalan di setiap unsur komponennya.

\section{Komponen Masukan (Input)}

Komponen masukan dalam implementasi pembelajaran dalam jaringan (daring) di SMK Negeri 1 Tanjuang Baru terbagi dalam empat indikator/sub indikator yang ditinjau dari pendidik, peserta didik, sarana prasarana, dan biaya. Berdasarkan angket yang disebarkan kepada 70 orang peserta didik dengan 24 butir pernyataan, diperoleh hasil untuk indikator pendidik sebesar 4,11 dengan tingkat pencapaian sebesar $82,18 \%$ dan termasuk ke dalam kategori baik. Artinya pendidik dalam implementasi pembelajaran dalam jaringan (daring) sudah mamiliki kemampuan dalam mengoperasikan komputer, mengakses internet, mengupload materi saat pembelajaran daring, dan memberikan arahan kepada peserta didik dalam memanfaatkan pembelajaran daring. Hasil untuk indikator peserta didik diperoleh rata-rata sebesar 4,00 dengan tingkat pencapaian sebesar 80,06\% dan termasuk ke dalam kategori 
baik. Artinya peserta didik dalam implementasi pembelajaran dalam jaringan (daring) sudah memiliki keterampilan dasar yang baik untuk melakukan pencarian di internet, memahami tentang teknologi informasi, mengikuti perkembangan teknologi, dan mampu mengoperasikan komputer.

Hasil untuk indikator sarana prasarana diperoleh rata-rata sebesar 4,07 dengan tingkat pencapaian sebesar $81,36 \%$ dan termasuk ke dalam kategori baik. Artinya sarana dan prasarana dalam implementasi pembelajaran dalam jaringan (daring) tersedia dengan baik yaitu sekolah sudah menyediakan akses ke internet, perangkat komputer, dan daya listrik untuk mengoperasikan komputer. Skor perolehan rata-rata dari ketiga indikator/sub indikator terkait komponen masukan implementasi pembelajaran dalam jaringan (daring) diperoleh sebesar 4,04 dengan tingkat pencapaian $80.71 \%$ dan termasuk ke dalam kategori baik. Dengan demikian dapat disimpulkan bahwa komponen masukan perlu ditingkatkan dan dioptimalkan untuk indikator pendidik dan sarana prasarana dalam implementasi pembelajaran dalam jaringan (daring) di masa yang akan datang. Hal ini disebabkan karena indikator pendidik dan sarana prasarana masih belum sesuai dengan standar yang telah ditetapkan. Berdasarkan penjelasan di atas dapat disimpulkan bahwa suatu program membutuhkan masukan yang baik terkait unsur dalam proses pembelajaran khususnya pembelajaran dalam jaringan (daring). Komponen masukan yang telah dievaluasi dan memperoleh hasil cukup perlu dilakukan perbaikan dan pengoptimalan di setiap unsur komponen.

\section{Komponen Proses (Process)}

Komponen proses dalam implementasi pembelajaran dalam jaringan (daring) di SMK Negeri 1 Tanjuang Baru terbagi dalam enam indikator/sub indikator yang ditinjau dari pelaksanaan pembelajaran dalam jaringan (daring), pelatihan SDM, pemanfaatan pembelajaran daring dalam penilaian hasil belajar, pemanfaatan sarana dalam implementasi pembelajaran dalam jaringan (daring), hambatan implementasi, dan solusi. Berdasarkan angket yang disebarkan kepada 70 orang peserta didik dengan 34 butir pernyataan, diperoleh hasil untuk indikator pelaksanaan sebesar 3,86 dengan tingkat pencapaian sebesar 77,14\% dan termasuk ke dalam kategori cukup. Artinya pelaksanaan implementasi pembelajaran dalam jaringan (Daring) cukup baik. Peserta didik cukup memahami materi yang diberikan pada saat pembelajaran dalam jaringan (daring), meluangkan waktu untuk mendayagunakan pembelajaran daring, dan cukup aktif di dalam proses pembelajaran dalam jaringan (daring). Hasil untuk indikator pelatihan SDM diperoleh rata-rata sebesar 3,57 dengan tingkat pencapaian sebesar $71,33 \%$ dan termasuk ke dalam kategori cukup. Artinya pelatihan SDM dalam implementasi pembelajaran dalam jaringan (daring) tergolong cukup. Sekolah cukup memberikan pelatihan/pengenalan mengenai pembelajaran dalam jaringan (daring).

Hasil untuk indikator pemanfaatan pembelajaran daring dalam penilaian hasil belajar diperoleh rata-rata sebesar 3,77 dengan tingkat pencapaian sebesar 75,37\% dan termasuk ke dalam kategori cukup. Artinya Pembelajaran Daring dalam penilaian hasil belajar cukup dimanfaatkan oleh pendidik. Hal ini terlihat dari peserta didik meninjau kembali pertanyaan yang ada dan jawaban yang akan di upload saat pembelajaran daring. Kemudian pendidik juga cukup memberikan batas waktu dalam pengumpulan tugas saat pembelajaran daring. Hasil untuk indikator pemanfaatan sarana dalam pembelajaran dalam jaringan (daring) diperoleh rata-rata sebesar 4,03 dengan tingkat pencapaian sebesar 80,63\% dan termasuk ke dalam kategori cukup. Artinya pemanfaatan sarana dalam pembelajaran dalam jaringan (daring) tergolong pada kategori cukup. Jaringan internet cukup mendukung implementasi pembelajaran dalam jaringan (daring), dan jumlah komputer juga cukup dalam implementasi pembelajaran dalam jaringan (daring). Walaupun pada praktik di lapangan masih kendala dalam pemanfaatan sarana. 
Hasil untuk indikator hambatan dalam implementasi pembelajaran dalam jaringan (daring) diperoleh rata-rata sebesar 3,88 dengan tingkat pencapaian sebesar 77,52\% dan termasuk ke dalam kategori cukup. Artinya hambatan dalam implementasi cukup dirasakan baik bagi pendidik dan peserta didik. Jaringan internet yang terputus saat mengakses pembelajaran daring, pemadaman listrik, dan fasilitas komputer yang tidak mencukupi. Hasil untuk indikator solusi diperoleh rata-rata sebesar 4,34 dengan tingkat pencapaian sebesar $86,71 \%$ dan termasuk ke dalam kategori baik. Artinya solusi yang diberikan oleh pihak sekolah maupun pendidik dalam meminimalisir permasalahan atau hambatan implementasi pembelajaran dalam jaringan (daring) sudah baik. Hal ini terlihat dari sekolah menutup situssitus yang dapat mengganggu proses pembelajaran dalam jaringan (daring), pemanfaatan komputer dilakukan secara bergantian/shif, dan apabila pemadaman listrik terjadi maka kelas dialihkan kepada pemberian teori oleh pendidik.

Skor perolehan rata-rata dari keenam indikator/sub indikator terkait komponen proses implementasi pembelajaran dalam jaringan (daring) diperoleh sebesar 3,91 dengan tingkat pencapaian $78,12 \%$ dan termasuk ke dalam kategori cukup. Dengan demikian dapat disimpulkan bahwa komponen proses perlu diperbaiki untuk indikator pelaksanaan, pelatihan SDM, pemanfaatan pembelajaran daring dalam penilaian hasil belajar, dan pemanfaatan sarana dalam implementasi pembelajaran dalam jaringan (daring) guna meminimalisir hambatan di masa yang akan datang, dan perlu ditingkatkan dan dioptimalkan untuk indikator solusi terhadap hambatan dalam implementasi pembelajaran dalam jaringan (daring).

\section{Komponen Hasil (Product)}

Hasil untuk indikator hasil dan dampak diperoleh rata-rata sebesar 4,51 dengan tingkat pencapaian sebesar $80,29 \%$ dan termasuk ke dalam kategori baik. Artinya hasil dan dampak yang diberikan dalam implementasi pembelajaran dalam jaringan (daring) sudah baik. Hal ini terlihat dari bertambahnya pengetahuan peserta didik dalam menggunakan media secara online, peserta didik menjadi lebih aktif dalam proses pembelajaran, menggunakan teknologi komputer dalam proses pembelajaran, dan peserta didik menerima inovasi teknologi dalam rutinitas harian. Berdasarkan data tersebut dapat disimpulkan bahwa hasil dalam implementasi pembelajaran dalam jaringan (daring) cukup baik. Pihak sekolah dan pendidik harus lebih meningkatkan dan mengoptimalkan pelaksanaan pembelajaran dalam jaringan (daring), dan memperbaiki komponen-komponen yang perlu diperbaiki seperti lingkungan, pendidik, dan sebagainya. Hasil dan dampak dari pembelajaran dalam jaringan (daring) dapat dirasakan manfaatnya apabila pelaksanaan perbaikan dari semua unsur yang menghambat dapat dilaksanakan setelah adanya evaluasi. Hal ini bertujuan supaya tujuan implementasi pembelajaran dalam jaringan (daring) dapat terwujud lebih baik..

Melihat kondisi pendidikan di Indonesia, saat ini pemerintah mewajibkan seluruh siswa, bahkan mahasiswa untuk belajar jarak jauh (daring) yang dilakukan dalam kurun waktu tertentu (Nengrum et al., 2021; Sadikin \& Hamidah, 2020). Hal ini dilakukan sebagai salah satu bentuk upaya Negara Indonesia dalam mencegah penularan Covid-19 dan tetap meningkatkan kualitas pendidikan di tengah pandemi Covid-19. Perlunya penguasaann teknologi mau tidak mau harus dilakukan baik siswa maupun bagi pendidik. Hal tersebut menjadi tantangan tersendiri bagi guru untuk memaksimalkan proses pembelajaran secara daring, dan tantangan bagi siswa untuk mengerti materi dan tugas-tugas yang diberikan saat pembelajaran daring (Surahman et al., 2020; Wahyono et al., 2020). Sistem pembelajaran dilaksanakan melalui perangkat personal computer (PC), laptop serta smartphone yang terhubung dengan koneksi jaringan internet (Yuzulia, 2021). Guru dapat melakukan pembelajaran bersama diwaktu yang sama menggunakan grup di media sosial seperti WhatsApp (WA), telegram, instagram, aplikasi zoom, aplikasi google classroom ataupun media lainnya sebagai media pembelajaran (Basilaia \& Kvavadze, 2020; Naserly, 2020). 
Dengan demikian guru dapat memastikan siswa mengikuti pembelajaran dalam waktu yang bersamaan, meskipun di tempat yang berbeda. Perlu disadari bahwa ketidaksiapan guru dan siswa terhadap pembelajaran daring juga menjadi masalah. Perpindahan sistem belajar konvensional ke sistem daring amat mendadak, tanpa persiapan yang matang (Ayuni et al., 2021). Tetapi semua ini harus tetap dilaksanakan agar proses pembelajaran dapat berjalan lancar dan siswa aktif mengikuti walaupun dalam kondisi pandemi Covid-19.

\section{CONCLUSION}

Berdasarkan hasil penelitian menunjukkan bahwa implementasi pembelajaran dalam jaringan (daring) di SMK Negeri 1 Tanjung Baru berada pada kategori cukup. Untuk itu perlu adanya perbaikan dan peningkatan pemahaman mengenai implementasi pembelajaran daring. Perbaikan dan peningkatan tersebut meliputi semua komponen dari implementasi pembelajaran dalam jaringan (daring). Pendidik dan peserta didik yang terlibat di dalam implementasi pembelajaran dalam jaringan (daring) perlu meningkatkan wawasan dan ilmu pengetahuan mengenai perkembangan teknologi. Implikasi dari penelitian ini adalah perlunya pihak sekolah melengkapi dan memperbaharui sarana dan prasarana sekolah, memberikan motivasi kepada pendidik dan peserta didik untuk lebih aktif di dalam implementasi pembelajaran dalam jaringan (daring). Selain itu, pihak sekolah juga perlu memberikan pelatihan-pelatihan yang berhubungan dengan pembelajaran dalam jaringan (daring) kepada pendidik dan peserta dan perlu membuat web learning yang baru yang mampu menyediakan fasilitas yang lebih lengkap.

\section{REFERENCES}

Arizona, K., Abidin, Z., \& Rumansyah, R. (2020). Pembelajaran Online Berbasis Proyek Salah Satu Solusi Kegiatan Belajar Mengajar Di Tengah Pandemi Covid-19. Jurnal Ilmiah Profesi Pendidikan, 5(1), 64-70. https://doi.org/10.29303/jipp.v5i1.111.

Ayuni, D., Marini, T., Fauziddin, M., \& Pahrul, Y. (2020). Kesiapan Guru TK Menghadapi Pembelajaran Daring Masa Pandemi Covid-19. Jurnal Obsesi : Jurnal Pendidikan Anak Usia Dini. https://doi.org/10.31004/obsesi.v5i1.579.

Ayuni, D., Marini, T., Fauziddin, M., \& Pahrul, Y. (2021). Kesiapan Guru TK Menghadapi Pembelajaran Daring Masa Pandemi Covid-19. Jurnal Obsesi : Jurnal Pendidikan Anak Usia Dini, 5(1), 414-421. https://doi.org/10.31004/obsesi.v5i1.579.

Basilaia, G., \& Kvavadze, D. (2020). Transition to Online Education in Schools during a SARS-CoV-2 Coronavirus (COVID-19) Pandemic in Georgia. Pedagogical Research, 5(4), 1-9. https://doi.org/10.29333/pr/7937.

Bhakti, Y. B. (2017). Evaluasi program model CIPP pada proses pembelajaran IPA. JIPFRI (Jurnal Inovasi Pendidikan Fisika Dan Riset Ilmiah), 1(2), 75-82. http://www.journal.stkipnurulhuda.ac.id/index.php/JIPFRI/article/view/109.

Cahyati, N., \& Kusumah, R. (2020). Peran Orang Tua Dalam Menerapkan Pembelajaran Di Rumah Saat Pandemi Covid 19. Jurnal Golden Age, 4(01), 4-6. https://doi.org/10.29408/jga.v4i01.2203.

Damayanthi, A. (2020). Efektivitas Pembelajaran Daring di Masa Pandemi Covid 19 pada Perguruan Tinggi Keagamaan Katolik. JURNAL SOSIAL :Jurnal Penelitian Ilmu-Ilmu Sosial, 21(3), 53-56.

Ding, J., Hermawati, D., \& Subakti, H. (2020). Analisis Media Pembelajaran Daring Di Era Pandemi Covid-19 Pada Kelas III SD Negeri 027 Samarinda Ulu. Sistema: Jurnal Pendidikan, 01(02), 16-23. https://doi.org/10.24903/sjp.v1i2.639.

Jariyah, A., \& Tyastirin, E. (2020). Proses dan Kendala Pembelajaran Biologi di Masa 
Pandemi Covid-19: Analisis Respon Mahasiswa The Biology Learning Processes and Constraints in the Covid-19 Pandemic Period: Analysis of Student Responses. Jurnal Penelitian Dan Pengkajian Ilmu Pendidikan: E-Saintika, 4(2), 183-196.

Kusuma, W. S., \& Sutapa, P. (2020). Dampak Pembelajaran Daring terhadap Perilaku Sosial Emosional Anak. Jurnal Obsesi : Jurnal Pendidikan Anak Usia Dini, 5(2), 16351643. https://doi.org/10.31004/obsesi.v5i2.940.

Naserly, M. K. (2020). Implementasi Zoom, Google Classroom, Dan Whatsapp Group Dalam Mendukung Pembelajaran Daring (Online) Pada Mata Kuliah Bahasa Inggris Lanjut. Journal of Chemical Information and Modeling.

Nengrum, T. A., Pettasolong, N., \& Nuriman, M. (2021). Kelebihan dan Kekurangan Pembelajaran Luring dan Daring dalam Pencapaian Kompetensi Dasar Kurikulum Bahasa Arab di Madrasah Ibtidaiyah 2 Kabupaten Gorontalo. Jurnal Pendidikan, 30(1), 1-12. https://doi.org/https://doi.org/10.32585/jp.v30i1.1190.

Nurhayati, S., Wicaksono, M. F., Lubis, R., Rahmatya, M. D., \& Hidayat, H. (2020). Peningkatan Kemampuan Guru Dalam Pembelajaran Daring Dengan Memanfaatkan Teknologi Informasi Bagi Guru SMA Negeri 5 Cimahi Bandung. Indonesian Community Service and Empowerment (IComSE), 1(2), 70-76. https://doi.org/https://doi.org/10.34010/icomse.v1i2.3878.

Rigianti, H. A. (2020). Kendala Pembelajaran Daring Guru Sekolah Dasar Di Kabupaten Banjarnegara. Elementary School, 7(2), 297-302. https://doi.org/10.31316/esjurnal.v7i2.768.

Sadikin, A., \& Hamidah, A. (2020). Pembelajaran Daring di Tengah Wabah Covid19:(Online Learning in the Middle of the Covid-19 Pandemic). Biodik, 6(2), 214-224. https://doi.org/10.22437/bio.v6i2.9759.

Sugiyono. (2014). Metode Penelitian Pendidikan Pendekatan Kuantitatif, Kualitatif, dan $R \& D$. Alfabeta.

Surahman, Santaria, \& Setiawan. (2020). Tantangan Pembelajaran Daring Di Indonesia. Journal of Islamic Education Management, 5(2), 89-98.

Wahyono, P., Husamah, H., \& Budi, A. S. (2020). Guru profesional di masa pandemi COVID-19: Review implementasi, tantangan, dan solusi pembelajaran daring. Jurnal Pendidikan Profesi Guru, 1(1), 51-65. http://ejournal.umm.ac.id/index.php/jppg/article/view/12462.

Yuzulia, I. (2021). The Challenges Of Online Learning During Pandemic : Students ' V oice. Jurnal Bahasa Dan Sastra, 13(1), 8-12. https://doi.org/10.31294/w.v13i1.9759. 